\title{
PHENOMENOLOGICAL STUDY ON THE VILLAGE FUND ACCOUNTABILITY
}

\author{
Dyah Maritafitri, Bety Nur Achadiyah \\ State University of Malang \\ Dyah.maritafitri@gmail.com
}

\begin{abstract}
Phenomenological Study On The Village Fund Accountability, This study analyzes the accountability perception on the management of village fund in Jabon Village, Jombang district based on the executor's experience. The selected type of research is a qualitative method that paradigm the interpretive phenomenology. Based on this research, the executor manages village funds based on the incidence of failure in the village timely disburse in May 2016. They have a perception that reporting is mandatory in order for them to get the village fund. The executor does not want to experience the disappointment 2016 to reoccur. Thus, they avoid the same incident as the result of learning from experience in managing the village funds in the previous year. At each experience, there is the environment that plays a role in the process of intersubjectivity. First, through skepticism among the executor based on the stereotype that the educational background determines capability. Second, the behavior of financial managers of the village where they are always obedient to the commands of the village head, this is a repetitive action that is considered reasonable. Both forms of intersubjectivity by the work environment caused executor system to justify a different form of the duties and functions or Tugas Pokok dan Fungsi (Tupoksi). Because of this, the executor has difficulties to integrate the village fund management responsibilities to be accountable. Executor defines accountability as the responsibility of reporting vertically, while horizontal reporting is only done as a formality. The greatest thrust of executors in action is the fear of sanctions from those who are considered to have a higher position in the bureaucratic corridor. Thus, the perception of accountability, in this case, is that the necessity in the management of village funds containing different levels of urgency differs based on the focus or concern of the work environment on the management of village funds.
\end{abstract}

Keywords: phenomenological studies, accountability, village fund. 


\section{JURNAL NOMINAL / VOLUME VII NOMOR 2 / TAHUN 2018}

\section{INTRODUCTION}

The village government has the freedom to manage its own finances in order to create independence at the village level. The national development from the village level is one of the programs of the Jokowi presidential government in 2014-2019. Therefore, the government issued regulations on village funds. Village funds are used to finance the implementation of governance, development implementation, community development, and empowerment. The village funds are distributed from the State Treasury Account or Rekening Kas Umum Negara (RKUN) to the Village Treasury Account or Rekening Kas Desa (RKDes) through the District Public Treasury Account or Rekening Kas Umum Daerah (RKUD). The village fund for 2016 is channeled in two stages, namely in March of $60 \%$ and in August of $40 \%$ of the total budgeted village funds. Government Regulation or Peraturan Pemerintah (PP) number 8 of 2016 states that each village in the regency/municipality is obliged to submit the village regulation concerning APBDesa and report on the realization of the use of village funds in the previous period to the regent/mayor. If the village head does not meet these requirements on time, the village funds belonging to the village will be detained in the RKUD.
Village funds are implemented since 2015. According to a report on the results of a village financial management review of 2015 by Corruption Eradication Commission or Komisi Pemberantasan Korupsi (KPK), there are potential problems in fund management in the village. Some of these potentials are the possibility of corruption / fraud by counterparts due to the weakness of the village apparatus, the time frame of the village budget management cycle which is difficult to follow by the village, the prepared apps that do not reflect the village needs, the use of plans and the accountability of the less transparent village, which have not followed the standard and are prone to manipulation, as well as the obligation of preparing accountability reports by inefficient villages. The preparation of an inefficient accountability report can lead to delays in disbursement of village funds if the accountability report is not completed on time. The problem occurred in eight villages in Jombang district. In early 2016 there were several villages in Jombang district reported problematic in the preparation of accountability reports on the use of village funds in the previous budget year. The problematic villages include Mojowarno Village, Mojowangi Village, Japan Village, Pagerwojo Village, Cangkringrandu Village, Ngudirejo Village 


\section{JURNAL NOMINAL / VOLUME VII NOMOR 2 / TAHUN 2018}

And

Jabon

Village

(newspkbJombang.com). Based on the information from the inspectorate of Jombang district, in Jombang sub-district, which has the worst financial management in terms of implementation and administrative is from Jabon Village. Therefore, the researcher decided to conduct research in Jabon Village.

The late disbursement of village funds in the first phase of the 2016 fiscal year into RKUD Jabon was due to the fact that village officials were unable to report accountability for the timely use of village funds. The village secretary of Jabon said that there is already a regulation from the central government and local government on village fund management mechanisms from the planning phase to the detailed reporting phase. In addition, supervision and coaching have also been provided by the local government of Jombang district to the village government. Based on the researcher's observation, the assistance done by local government is done directly and indirectly. Direct facilitation forms are technical training seminars by district and BPMPD which are usually held in September simultaneously. While the form of indirect assistance is in the form of guidance and advice given to the village government when the district team is following Rural Development Plan Meeting or Musyawarah Rencana
Pembangunan Desa (Musrembangdes), visiting the village, and conducting regular checks.

The availability of regulation, assistance, and socialization has not made the village of Jabon able to complete the obligation of village fund management until the reporting stage. According to the researcher, although there are detailed regulatory means and regulations, if the apparatus as the executor involved does not consider accountability an obligation, then accountable management of village funds will not be created. Researchers argue that accountability is not just the fulfillment of financial reporting obligations by the accountor to the accountee. Rather as the implementation of authority that is in accordance with the commitment of the accountor and can be implemented thoroughly at every stage. Researchers interpret accountability as a duty to fellow human beings and to God in performing the authority and trust that has been given to the accountor. When a person understands something deeply, then this can encourage action in accordance with the perception that has been implanted. The researcher's epoche is corroborated by an explanation of a Sobur (2013: 220) that a person who has perceptions in his life can survive and thrive even in difficult situations because perception gives the courage to act. 


\section{JURNAL NOMINAL / VOLUME VII NOMOR 2 / TAHUN 2018}

Therefore, researchers are interested in tracking perceptions of accountability in village fund management according to the apparatus involved in managing village funds.

The purpose of this study is to explore the management of village funds to obtain essential accountability perceptions in Jabon Villages, not to measure achievement of accountability or to analyze influence. The individual's awareness of the experience of personal experience shapes his perspective against a different phenomenon from the other individual (Solso, 2007: 240). Each experience must have an interaction process so intersubjective also play a role in shaping a perception. If reflected in the financial management of Jabon Village, the experience of each apparatus shapes his perspective on a phenomenon to be different from other apparatus. This resulted in the perception of accountability that was formed in the village of Jabon cannot be generated. In addition, there is a different social interaction process within each experience of managing village funds. Therefore, the environment of the village fund management apparatus also plays a role in shaping perceptions of accountability. According to the researchers, the implementation of a village fund management system that has been regulated by the central and regional governments depends on the apparatus as a human resource implementer in interpreting accountability. Based on the description that has been described, the researcher concludes three main questions, namely

1. How do informants interpret and respond to their experiences related to village fund management?

2. How does the work environment play a role in the formation of informant experiences related to village fund accountability?

3. How did the experience shape the reality of village fund accountability currently occurring in Jabon Village?

\section{LITERATURE REVIEW}

The process of perception is inseparable from intersubjectivity factor. Therefore, the researcher explains the interrupt process of intersubjectivity using the stimulus theory of the Dollar and Miller response theory, the social relief construction theory of Peter Berger and Thomas Luckman, and the theory of symbolic interaction by Mead and Blummer. The response stimulus theory studies the relationship between stimulus and response, where an event greatly affects the relationship between response to cue/stimulus (Alwisol, 2009: 337). There are four main components in this theory that 


\section{JURNAL NOMINAL / VOLUME VII NOMOR 2 / TAHUN 2018}

is, 1) Drive, is an internal stimulus in the human that encourages him to do something but does not determine the form of his actions, 2) Cue, is a stimulus that gives the signal the need for a response, 3 ) Response, someone who is associated with the stimulus in succession if the response has been done before, 4) Reinforcement, is a drive reduction (Alwisol, 2009: 339-340). The next theory is the construction theory of social reality that explains how the social world is formed. This theory says that every individual in his life develops a repetitive behavior that becomes a habit that allows the individual to act automatically. In social interaction, each individual will observe and respond to the habits of other individuals so that this allows for adjustment (Kuswarno, 2009: 112). The next theory is the theory of symbolic interaction that says that social reality is formed by the interaction between individuals. Interaction allows individuals to gain perception during the exchange of information within social groups (West and Turner, 2008: 98-100). Individuals will move to act based on perceptions implanted on people, objects, and events in the past. Thus, an action can occur because of the perceptions gave by others and created during the interaction process and modified through the interpretive process (West and Turner, 2008: 98).
In addition to the above three theories, this study also uses a study of public accountability and regulation of village funds as a comparison between reality and normative. Based on the theory of accountability mentioned by Kang and Cho (2016: 2), Senses (2010: 385), Mardiasmo (2002: 22) Guillermo O'Donnell in "Horizontal Accountability in New Democracies" (1998), it can be concluded that accountability is the accountability of public sector executors vertically to higher government in bureaucratic corridors and horizontally to society for all actions and decisions as ordered. Owners of interest can assess performance and monitor compliance from executors in the public sector in accordance with applicable ethics and legislation in order to create good and democratic governance during the process of achieving goals. Implementation of accountability not only focuses on reporting the completion of a responsibility but also the execution of its responsibilities honestly and in accordance with applicable law or regulation. Meanwhile, based on research conducted by Mutiganda (2013: 11), it can be concluded that accountancy made by the accountor formed by the enactment of environmental policy that reality runs in accordance with the expectations of the accountee so that the accountability of an 


\section{JURNAL NOMINAL / VOLUME VII NOMOR 2 / TAHUN 2018}

institution cannot be equated to other institutions.

Research on accountability related to financial management in the previous village scope has been done by Setyoko in 2011, Ula in 2014, Irma in 2015, Fajri, Endah and Siswidiyanto in 2015, and Riyanto in 2015. The five previous studies have concluded that the poor quality of human resources in the management of financial administration at the village level is a major factor in accountability of village financial management that is not yet optimal. In this study, researchers try to find out how informants interpret accountability by analyzing the process of formation of these perceptions through their experience in carrying out the responsibility of managing the village funds. The village fund itself is one source of village income derived from the State Budget or Anggaran Pendapatan dan Belanja Negara (APBN) which is transferred through Regional Revenue and Expenditure Budget or Anggaran Pendapatan dan Belanja Daerah (APBD) districts/cities for the benefit of the village. The Village Fund or Dana Desa (DD) is different from the Village Fund Allocation or Alokasi Dana Desa (ADD). The allocation of village funds is an obligation of district / municipal governments to allocate budgets for villages derived from Profit Sharing or
Dana Bagi Hasil (DBH) and General Allocation Funds or Dana Alokasi Umum (DAU), both of which are part of the balancing funds. However, village funds are an obligation of the central government to allocate a transfer budget from APBN for the village. Villages that do not meet the requirements within seven days, then subject to witness the delay of transfer of village funds from RKUD to RKDes. If village funds are not channeled maximally from the district/municipality governments to the village until the end of the fiscal year, the remaining village funds become part of the rest of the budget. The village finance management mechanism including village funding is generally contained in the Minister of Finance Regulation No. 49/07/2016, Government Regulation $113 / 2004$ on village financial management, and government regulation no. 8 year 2016 . The existence of village funds is expected to improve the welfare and equity of village development through improving public services in the village.

\section{RESEARCH METHOD}

This research is a qualitative paradigm interpretive research using phenomenology method. This phenomenological research tries to understand the experience of the Jabon Village apparatus in managing accountable village funds. This research was conducted 


\section{JURNAL NOMINAL / VOLUME VII NOMOR 2 / TAHUN 2018}

in Jabon Village, Jombang Sub-District, Jombang Regency, East Java Province. The majority of data obtained through the indepth interview with semi-structured method and observation. Observations are made by observing the behavior of village fund managers both during the interview process as well as when they perform the task of financial management. In addition, researchers follow the Musrembangdes activity held on 16 January 2017 at 20:40 until 22:00. Informant in this research is village secretary named Mr. Robil, village treasurer named Mr. Andik, development staff named Mr. Purwadi, apparatus from BPKAD budget division named Mr.Aris, head of Family Welfare Development or Pembinaan Kesejahteraan Keluarga (PKK) named Mrs. Endang, apparatus from Jakarta Regency Inspector named Mr. Yoyok, and a citizen village. Informants from BPKAD and inspectorate are outsiders from the experience of village fund executor in Jabon. The reason researchers interviewed outsiders was to reinforce the fact that the phenomenon raised was indeed happening and experienced by the village of Jabon. Interviews with village fund executor informants were conducted from October 2016 to January 2017.

During the interview, the researcher was required to interact with the village apparatus of Jabon naturally and not prominently so that the researcher got pure subjectivity and understood the point of view and direct experience of the informant, as revealed by Sobur (2013: 425) and Kamayanti (2016: 150). Therefore, the researcher separates the researcher's assumptions and puts them in the preliminary research, then forgets them for a moment during the data collection phase. This stage is called epoche, is to let the reality as the original to rule out the experience and knowledge of researchers (Kuswarno, 2009: 48). The researcher's job is to capture the phenomenon in the informant's statement using bracketing to find its purity. The process of bracketing is the beginning of the phenomenological reduction stage. Phenomenological reduction helps researchers to separate the textural perceptions contained in the noema and structural perceptions contained in informant noesis (Kuswarno, 2009: 49). Noema in this study is an objective description of the accountability of village funds visible by the senses accompanied by accurate evidence. In contrast, noesis is the ideal side of accountability for each informant's version and not a real accountability. Once perceptions are collected, the next stage is horizontalizing by combining the statements of all informants according to the unit of perception. The horizon stage is the process of releasing informant perceptions and 


\section{JURNAL NOMINAL / VOLUME VII NOMOR 2 / TAHUN 2018}

pouring them into several themes to be organized into textural descriptions (Kuswarno, 2009: 49-51). The final stage is to intuitively integrate textual and structural descriptions. The synthesis of harmony noema/texture and noesis / structural can reveal the essence of accountability of typical village funds belonging to Jabon Village (Kuswarno, 2009: 43-44).

\section{RESULT AND FINDING}

There are interesting phenomena that occur in the village of Jabon ranging from planning, implementation, and reporting. First, at the planning stage is the gap of treatment between physical development program development with nondevelopment programs. Based on observation of the researcher during Musrembangdes, the deliberation focused on discussing the physical development program only and did not discuss the community empowerment program. This is because the budget sometimes does not fit the needs of community empowerment and its implementation is less desirable by the community.

Secondly, in the initial stage of implementation, the mechanism of disbursement of village funds from RKUDES is different from the regulation of village financial management. In reality, village funds are directly handed over to the technical executor simultaneously according to the Budget Plan or Rencana Anggaran Biaya (RAB) through the realization deliberation. Meanwhile, according to the regulation, the terms of a number of funds can be taken from RKUDES is the existence of documents of the letter of responsibility liability or Surat Pertanggungjawaban (SPJ). That is, village funds can only be submitted to the executor if the transaction of goods/services has occurred. Thirdly, there is a phenomenon whereby executors seek administrative execution to proceed according to the $\mathrm{RAB}$ in terms of budgets by manipulating evidence of transactions or using personal money to realize the realization report in accordance with the budget in the RAB. Executor considers the complete implementation of the program according to the $\mathrm{RAB}$ is the main goal. The process pursued to achieve that goal does not become the attention of the informant. The act of manipulating the notes and the working ethics that are not in accordance with the main tasks and functions or Tugas Pokok dan Fungsi (Tupoksi) is required as long as the implementation is in accordance with the RAB. The executor works by not referring to Tupoksi but to the command of the village chief.

Fourth, a phenomenon related reporting activities. SPJ development activities always finish faster than SPJ community empowerment activities. 


\section{JURNAL NOMINAL / VOLUME VII NOMOR 2 / TAHUN 2018}

Therefore, SPJ development activities prioritized for the village of Jabon not get sanction in the form of detention DD stage II by Jombang District Government. Meanwhile, SPJ community empowerment activities are completed by the end of the year before the reporting period. The overall reporting activity should be completed in December 2016, but the SPJ is completed by January 2017. According to the executor, the preparation of SPJS that take longer than reporting deadlines is normal. The last phenomenon is the control mechanism of DD management that is done in stages. The implementation of the physical development is coordinated by the development staff, while the whole is monitored by the village head through the village secretary for subsequent submission to the sub-district and supervisory parties, namely the inspectorate. The village executives acknowledge that controls will be better and they will be more eager to assume responsibility if supervised by the inspectorate.

\section{DISCUSSION}

Preaching in early May of 2016 on Jabon Village unable to complete accountability reports became a lesson for village fund management executors. Executor understands that they are required to complete the realization report of SPJ so they can disburse village funds (DD) next period. If they fail to meet the report deadline, then the consequences are not only hampered the program implementation, but also the mental burden. The Jabon Village that was once late in disbursing village funds from RKUD into RKDes resulted in the village becoming the public spotlight. The event was an embarrassing experience for village fund management executors. According to the stimulus and response theory, feelings of shame are the primary drives in executors that encourage them to perform avoidance responses (Alwisol, 2009: 338-339). The form of an avoidance response in order not to re-experience the embarrassment of past events is by 1) being alert to those whom they consider being outside their social group, 2) prioritizing the reporting of physical development as a top priority, and 3) striving for the suitability of funds village according to $\mathrm{RAB}$.

A wary attitude is seen in the executor's statement during the interview. They do not want to appear dominant in a phenomenon they perceive as risky to use the word "we" rather than "me" to merge themselves with other subjects. The second reversal response undertaken is to prioritize the physical development SPJ reporting, while the SPJ for community empowerment and government operations is used as the last ammunition. The requirement to take 


\section{JURNAL NOMINAL / VOLUME VII NOMOR 2 / TAHUN 2018}

the village fund of phase I of RKUD is the village must complete the report on the realization of the use of village funds in the previous budget year. Meanwhile, the requirement of village fund for phase II is the realization report on $50 \%$ of the use of village fund of phase one. The period of taking the village funds from RKUD to be deposited into the village is a maximum of seven working days from the time the village funds are transferred from RKUN to RKUD. The regulation requires the village of Jabon to complete $50 \%$ of the realization report in order to obtain the village fund for phase II. Based on experience in managing village funds in 2015, the SPJ completed ahead of others is the SPJ of the physical development program. This is due to the linkage with a third party (private) such as the appointed PT or CV or the holder of the construction contract. The involvement of the contract holder facilitates the village to complete the consolidation of the physical development of the village. Thus, the village executor judged that the physical development SPJ is a hope for the village of Jabon to immediately take the village funds from RKUD to RKDes. This perception is the reason for the village fund executor to treat physical development as a realization report that must be completed and reported first. The inequality of perception between physical development SPJ with SPJ community empowerment and rural operational become the reason for the implementation of non-development SPJ upon the end of year reporting period. Thus, the obligation to accumulate, then SPJ reporting on the total use of village funds in one budget year to be delayed.

During the execution, the executor understands that no matter what happens, the most important is the similarity between the amount of expenditure listed on the proof of transactions with those listed in the RAB budget. The perception is learned from the experience of the executor while undergoing the examination process. At the time of the examination, the main focus of the examination is to match the report and its physical goods with the RAB. Supervisors, both from the district and the inspectorate, monitor the implementation by inquiring about administrative developments. The supervisory party does not provide the perception that the SPJ should be absolutely equal to the RAB. But indirectly, the interaction that exists during the examination, the Jabon Village executive interprets that the fairness of the SPJ is judged from the implementation in accordance with the RAB of the administrative terms. Such intersubjective perceptions are the result of interaction between the Jabon Village executor and the supervisor, the inspectorate, and the subdistrict officer. In other words, village fund 


\section{JURNAL NOMINAL / VOLUME VII NOMOR 2 / TAHUN 2018}

executors give perceptions of the relationship between the implementation of village funds and the realization reports based on the perceptions that have been embedded to them through the interaction process (West and Turner, 2008: 100). If there is a difference between the budget and the actual cost, then the way they choose is to manipulate the evidence of the transaction or use personal money to equate the difference of non-conformity with the RAB. Such practices have been repeated and legalized by the working environment of the Jabon Village fund administrators. The executor's environmental response allows for adjustment until it becomes a common manipulation habit, thus creating a reality of imposed conformity to the implementation of village funds in accordance with the RAB. (Kuswarno, 2009: 112).

In the formation of experience, each executor experiences an intervention of the work environment in instilling perception through intersubjectivity (Sobur, 2013: 53). The process of intersubjectivity occurs through stereotypes and skepticism amongst Jabon Village fund management executors, as well as customs owned by Technical Executives of Village Financial Management or Pelaksana Teknis Pengelolaan Keuangan Desa (PTPKD). Educational stereotypes that reflect the capabilities already inherent in the working environment of Jabon Village. Village fund management executors with undergraduate education background are assessed to have broader insight and capability than graduate executors. The stereotype triggered a skeptical attitude among village fund management executors so that they would give each other a perception of one another. According to the theory of symbolic interaction, an executor can treat himself or herself based on the perceptions that his environment has instilled through interaction with co-workers (West and Turner, 2008: 101). This is what happens between executors from the village government and village institutions. The village government considers that the requirement for village institutions to develop programs that benefit the empowerment of rural communities does not maximize the capacity and creativity of village institutions. Meanwhile, village institutions consider that they are not authorized in the planning so that the existing empowerment program is tailored to the program of the district government. As a result, Musrembangdes dated January 16,2017 , only focuses on planning and discussing physical development programs only, not for community empowerment programs. In fact, physical development programs, community empowerment, and government operations financed by village 


\section{JURNAL NOMINAL / VOLUME VII NOMOR 2 / TAHUN 2018}

funds are implemented in accordance with the RAB agreed by village governments, village institutions, and communities at the Musrembangdes forum.

The village fund executor understands that the needs of Jabon Village are different from other villages so that the programs and budgets cannot be generalized. Nevertheless, they do not deliberate empowerment proposals, such as physical development, with enthusiasm. Executors from village institutions have been convicted that they are unable to determine their own empowerment program. The silence shown by the village institution to the perceptions given by other executors to them is due to skepticism (West and Turner, 2008: 101). Parties from village institutions say they are less motivated to run program responsibilities because the programs budgeted in the $R A B$ are less in line with their wants and needs. Based on the illustrations, it can be concluded that skepticism has a share in the reality of accountability, i.e. the reporting of village institutions that are not timely due to less motivated executors to solve responsibilities.

Skeptical attitude due to educational stereotypes is also shown by village executors at work. Executors who are deemed incapable will let their responsibility be left to those deemed more capable by the social environment. For example, the operation of village financial information system or Sistem Informasi Keuangan Desa (SIMKUDA) is done by the village secretary instead of treasurer. Village secretaries with undergraduate background and civil worker status are considered to have more capabilities than village treasurers. In fact, the village secretary is sometimes involved in the preparation of SPJS of village institutions. Based on the results of the analysis, the work system executor does not run in line with Tupoksi, but according to the stereotype rule ala Jabon Village. An educational stereotype that reflects the capability raises a skeptical attitude towards executors who have a low educational background. According to the theory of symbolic interaction, the executor in this study can take action to himself. They perceive themselves as others see themselves (West and Turner, 2008: 98). They will give up the responsibilities they have to others who are deemed able to perform. For executors, the recognized ability is an important point in performing obligations and accountability for village fund management. So, they mean that the management of village funds can be accounted for if done by a more recognized party ability. 


\section{JURNAL NOMINAL / VOLUME VII NOMOR 2 / TAHUN 2018}

It is not only educational stereotypes that stimulate village fund managers that are inconsistent with the Tupoksi, but also obedience. Obedience is demonstrated by the technical executive of village financial management (PTPKD) in response to the village head's order. If investigated more deeply, the submissive response to the village head's current command does not just appear but has become a habit of hereditary. According to the theory of the construction of social reality, this can happen because the habits of many years belong together, then taught to the next generation so that they play the same role (Kuswarno, 2009: 112). For many years the executor was not familiar with the administration and management of villagestyle bureaucratic finances. Then in 2014, villages are given the authority to manage their own finances with the subsequent regulation of village finance, namely Regulations of Minister of Home Affairs 113 year 2014 and grants of villages totaling billions. However, this is not accompanied by the readiness of executors to change the dominant habits that have been inherent for many years.

The village head with the highest authority in the village area holds the cash control which is part of the duties and functions of a village treasurer. According to the theory of public accountability about the dimensions of honesty accountability, the phenomenon can be categorized as an act of abuse of power (Mardiasmo, 2002: 22). Meanwhile, the Jabon Village executive did not consider the village chief to abuse his power. The position of the village head that is not easily obtained creates a perception among the executor that the village head is the leader and the ruler of the village, his command is absolutely carried out. Executor Jabon Village itself prefer to keep the working atmosphere remain comfortable and pleasant than to trigger a conflict or tension due to reject the command of the village head. These reasons stimulated the dutiful response of the Jabon Village fund administrators. When analyzed by the theory of construction of social reality, the relationship between the village chief's command and the obedient attitude of the executor is stable so as to create a habit of executors who choose to work according to the village chief's command despite deviating from Tupoksi (Kuswarno, 2009: 112). In village finance management, each executor (executive) has a series of sustainable responsibilities. If one escapes the control of the executor, it will be difficult to integrate into a full set of responsibilities. The treasurer who does not hold the control of the cash and the village head acts as if the treasurer illustrates that there is no separation of functions among 


\section{JURNAL NOMINAL / VOLUME VII NOMOR 2 / TAHUN 2018}

village finance executors. According to Regulations 113 of 2014 on Village Financial Management, the treasurer has the duty: to receive, to keep, to pay, to administer, and to account for revenue and expenditure of village income. The treasurer is allowed to save money in the village treasury at a certain amount in order to meet the operational needs of the village government. Meanwhile, the treasurer of Jabon Village did not keep cash and did not know the transaction activity, but still required to prepare accountability report of cash usage. Thus, the treasurer finds it difficult to integrate the set of responsibilities of a treasurer as PTPKD as a whole.

The mechanism of village financial management according to pp 113 of 2014 is the submission of a Payment Order or Surat Perintah Pembayaran (SPP) by the prospective user of funds to the secretary. Spp filing requirement is SPJ, meaning that there has been a transaction of goods or services. After the verification by the secretary and received the signature from the village head, the treasurer can take funds from RKUDes for the sake of physical development, empowerment, or charging the village government. According to the theory of public accountability that explains the dimension of legal accountability, the requirement of the use of public funding sources is the guarantee of compliance with regulations (Mardiasmo, 2002: 22), pp 1132014. Meanwhile, what happens in Jabon Village is different from the village financial management mechanism. This is because the village head is in charge of the cash and can easily take funds from RKUDes without the completeness of the SPP document. That is, cash from RKUDes can be taken at any time even though SPJ has not been compiled. The village financial management environment in Jabon is accustomed to cash management mechanisms that do not comply with regulations so they do not protest. The PTPKD habits in liquefying the village cash without an SPP, prompting the executor to override SPJ. PTPKD is sole to complete the SPJ only if the inspectorate wants to do an inspection or only if the time is nearing the reporting schedule. According to the stimulus-response theory, information about the arrival of the examiner or reporting deadline is a signal that gives a hint that the executor should immediately complete the preparation of SPJ (Alwisol, 2009: 340). The executor relies on stimuli in the form of surveillance or inspection from the district and the inspectorate to solve the village fund management responsibilities. The PTPKD behavior that the researcher has submitted is repetitive so 


\section{JURNAL NOMINAL / VOLUME VII NOMOR 2 / TAHUN 2018}

as to create the reality of reporting the SPJ which is always delayed.

The learning process of village Jabon fund managers from the experience of managing village funds that are interventions of work environment through intersubjectivity by co-workers have shaped the perception of accountability typical of Jabon Village. Executor regards accountability as an implementation that requires responsibility. When calling the word "responsible", the attention of the informant refers to the SPJ reporting process. The executor of Jabon Village fund stated that SPJ is very important and absolute. They emphasize the word "very important" and "absolute" as if to convince researchers that such is the way they treat SPJ. According to stimulus-response theory, language is a gesture response and word selection as a reinforcement of a person's verbal behavior. The executor's response to the researcher was sparked by the question of "accountability" (Alwisol, 2009: 339). That is, the word "accountable" is a cue to the need for a response in an attempt to convince researchers (Alwisol, 2009: 340). Thus, it can be concluded that the perception of accountable village fund management for executors is capable of completing the SPJ report.

Public accountability is not just about reporting, but also on how the accountor can be honest in exercising his / her authority, obeying the laws of regulation, orderly in performing his duties by not neglecting administrative procedures, attentive in considering the achievement of objectives on every decision, and being aware of the responsibilities to accountee. This is as described in the theory of public accountability about the dimension of accountability (Mardiasmo, 2002: 22). However, because perceptions of accountability in Jabon Village tend to report, it is not uncommon that the program implementation process is realized without considering the dimension of public accountability. For example, on the implementation of development for the hamlet area completed by the $\mathrm{cv}$ of the village head. As disclosed by the treasurer and executor of the activity executive team (TPK), the development is carried out by the $\mathrm{CV}$ of the village head and coordinated by the development staff or the village government's internal party. Meanwhile, the theory of public accountability says that the dimension of accountability requires the awarding of tender contracts to be fair in order to avoid Corruption, Collusion and Nepotism or Korupsi, Kolusi dan Nepotisme (KKN) (Mardiasmo, 2002: 22).

A research conducted by Mutiganda explains that accountant's accountability is 


\section{JURNAL NOMINAL / VOLUME VII NOMOR 2 / TAHUN 2018}

formed based on policies in an environment that runs according to the expectations of the accountee (Mutiganda, 2013: 11). The results of this study show the phenomenon has happened in Jabon Village. The village fund executor considers that an important accountability point lies in reporting and sees that the reasonableness of SPJ can be seen in terms of its compliance with the RAB. Such perceptions are embedded in them during the management of village funds in the first year. For executors, SPJ is proof that they have completed their responsibility in using village funds that have been granted by the central government.

The executor feels that SPJ is inevitable in the process of raising funds from RKUD. This opinion is a form of explicit consciousness of the executor (noema) caused by the experience of sanction of incarceration in stage I of 2016, which in the end becomes the subject of conversation in public media. This event builds a deeper awareness that it is incumbent upon the executor to arrange the village to get the right of village funds to run the development program and empower the village community (Kamayanti, 2016: 46). They do not want to be judged to be incapable of managing village funds, perceived to have committed deviant acts, or are distracted by attempts to avoid legal issues. For them, oversight of DD management is much stricter than supervision of add management. The executor relies on the supervision of a higher work unit to motivate the completion of the accountability report.

The attention of village fund executors focuses on accountability, i.e. vertical reporting, as a motivation to manage village funds according to legislation. The theory of public accountability by O’Donnell in "Horizontal Accountability in New Democracies" (1998) says that public accountability demands require accountor to balance vertical and horizontal accountability. Meanwhile, accountability horizontally in the village of Jabon just done as a formality. At the time of Musrembangdes, the executor from the village apparatus only read out the results of the physical construction that was successfully completed thanks to the village funds. In fact, activities funded by village funds are not only physical development but also village government activities and community empowerment. Submission of accountability report by the executor to the community is done verbally and not in the form of visual evidence. On the other hand, the people of Jabon Village seem indifferent to the use of village funds, especially in non-development programs 


\section{JURNAL NOMINAL / VOLUME VII NOMOR 2 / TAHUN 2018}

during Musrembangdes. The apathetic response of the Jabon Villagers reinforces the perception of horizontal accountability of the village version of Jabon. Village fund managers as executors (executives) interpreted that the horizontal accountability is done by simply informing them that they have used village funds to build the community environment. These perceptions are formed through definitions during Musrembangdes activity, i.e. when executors and society interact. In the event, the public received the submission of accountability report conducted by the executor. As West and Turner (2008: 101) say in the theory of symbolic interaction, perception is created from interactions between people or can be called a social product. According to the Jabon Village executive, the development and empowerment program that has been perceived by the community is a form of horizontal accountability.

\section{CONCLUSION}

1. Executor interpreted and responded to his experience related to the management of village funds

Based on the experience in May 2016, the executor interpreted that they are required to complete the realization report of SPJ so they can disburse the village fund next period. If they fail to meet the reporting responsibilities, then the consequences are not only the slowdown of program implementation but also the addition of mental burden. Feelings of shame when highlighted by the media and the public to be stimuli from within the self that encourages the desire to "learn" so as not to feel the experience again. Based on the learning outcomes from experience, the Jabon Village fund executive undertook the avoidance response done with some action.

First, the executor is wary of the party not belonging to his social group. Executors refuse to be considered dominant in phenomena they perceive as risky. This shows that in noesis they know which action is deviant or can be bad. In the end, the executor generalizes or merges himself with another subject as a pseudo-face that covers his noesis.

Second, prioritize the reporting of physical development for the immediate grant of village funding, while the SPJ for community empowerment and government operations is completed at the end of the fiscal year prior to the reporting period. Executor understands that for the smoothness of the disbursement of village funds, it is better to prioritize the reporting of physical development SPJ. On the other hand, SPJ for community empowerment and government operations is completed by the end of the fiscal year, ahead of the reporting period. 


\section{JURNAL NOMINAL / VOLUME VII NOMOR 2 / TAHUN 2018}

Third, the executor seeks to match the implementation of village funding according to the RAB even through the manipulation of transaction evidence. They conclude that the proper implementation of village funds is when nominal spending is in line with the RAB. Therefore, they mean that the most important in the preparation of SPJ is to adjust the amount listed in the $\mathrm{RAB}$ in accordance with the nominal listed on the note and receipt. Such perceptions encourage executors to manipulate notes or receipts.

Thus, the three avoidance responses done by the executor are the result of learning from experience. They interpret the experience that has been learned. Then they respond or act on that perception.

2. The work environment plays a role in establishing the experience of village Jabon fund administrators with accountability of village funds

The Jabon Village fund executor interpreted his actions in the management of village funds in the same way as they had experienced, directly or indirectly. Indirect experience in question is to observe the interaction that occurs among colleagues. Therefore, the role of the working environment in the experience of the Jabon Village fund executive takes place through an intersubjectivity process.
First, through stereotypes and skepticism amongst Jabon Village fund management executors. Executor interprets the financial management capabilities based on educational background. Educational stereotypes reflect the capability to elicit skepticism towards executors with educational backgrounds at the bottom. Perceptions based on these stereotypes are accepted and interpreted by executors in managing village funds. For executors, a recognized ability is an important point in performing obligations and accountability for village fund management. They concluded that to make responsible village fund management, it must be done by a more recognized party of its ability. Thus, sometimes executors do not work in accordance with Tupoksi.

Secondly, through the repetitive behavior of PTPKD, that is always obedient to the request/command of the village head. The position of the village head that is not easily obtained creates the perception that the village head is the leader and the ruler of the village, his command is absolutely carried out. Executors prefer to keep the working atmosphere comfortable and enjoyable rather than triggering conflict or tension. The reason is to stimulate the dutiful response of the Jabon Village fund executive so that the relationship is stable. The village's financial management environment in Jabon is accustomed to such 


\section{JURNAL NOMINAL / VOLUME VII NOMOR 2 / TAHUN 2018}

conditions and does not protest. Thus, it creates a custom executor who chooses to work according to the village chief's command although different from Tupoksi.

Thus, the two forms of intersubjectivity by the work environment cause the executor to forget the reality that the working system of the village of Jabon goes unsuited to Tupoksi. In village finance management, each executor (executive) has a series of sustainable responsibilities. If one escapes the control of the executor, the executor will find it difficult to integrate it into accountable village fund management.

3. Realities of accountability of Jabon Village funds

When discussing accountable management, the executor's attention refers to vertical accountability. Accountability for village fund management executor in Jabon is to complete the preparation and reporting of SPJ to Jombang regency government. While horizontal accountability is simply done as a "formality". The perceptions of accountability for Jabon Village tend to report, but do not consider the dimensions of honesty accountability and compliance procedures in their implementation. For them, accountability is the management of village funds containing varying degrees of urgency based on the work environment's focus or concern on the management of village funds.
The biggest driver stimulus the executor has for action is the fear of sanctions. The sanctions in question are sanctions from parties considered to have a higher position in the bureaucracy. The executor relies on cue in the form of surveillance and inspection from the district and the inspectorate to complete the responsibilities of village fund management. Thus, the reporting of the realization of the use of village funds to the local government of Jombang regency at the end of the year is always delayed. On the other hand, accountability to the community in the form of delivery of the program is only through Musrembangdes.

\section{REFERENCES}

Alwisol. 2009. Psikologi kepribadian: edisi revisi. Malang: umm press.

Bastian, indra. 2010. Akuntansi sektor publik: suatu pengantar edisi ketiga. Jakarta: penerbit erlangga.

Creswell, john. 2015. Penelitian kualitatif dan desain riset: memilih di antara lima pendekatan. Yogyakarta:pustaka pelajar

Fajri, rahmi., setyowati, endah., \& siswidiyanto . 2015. Akuntabilitas pemerintah desa pada pengelolaan pengelolaan alokasi dana desa (studi pada kantor desa ketindan, kec lawang kab malang). Jurnal administrasi publik 3 (7): hlm. 1103 (online), dalam (http://administrasipublik.studentjourn al.ub.ac.id/index.php/jap/article/view/9 20), diakses 20 agustus 2016. 


\section{JURNAL NOMINAL / VOLUME VII NOMOR 2 / TAHUN 2018}

Sobur, alex. 2013. Filsafat komunikasi: tradisi dan metode fenomenologi. Bandung: remaja rosdakarya

Irma, ade. 2015. Akuntabilitas pengelolaan alokasi dana desa di kecamatan dolo kabupaten sigi. Katalogis 3 (1) : hlm. 136, (online), dalam (http://jurnal.untad.ac.id/jurnal/index.p $\mathrm{hp} /$ katalogis/article/view/4254), diakses 20 agustus 2016

Kamayanti, ari. 2016. Metodologi penelitian kualitatif akuntansi: pengantar religiositas keilmuan. Jakarta: yayasan rumah peneleh sari media dan literasi

Kang and cho. 2016. A study on the accountability of the regional r\&d program: the case of apctp. Springer 2 (3): hlm. 2, (online), dalam (http://link.springer.com/article/10.118 6/s40852-016-0029-9), diakses 20 agustus 2016.

Kuswarno, engkus. 2009. Metode penelitian komunikasi fenomenologi. Bandung: media padjadjaran.

Laporan hasil kajian pengelolaan keuangan desa: alokasi dana desa dan dana desa. (online), (http://www.keuangandesa.com), diakses 15 agustus 2016.

Mardiasmo. 2002. Akuntansi sektor publik. Yogyakarta: andi.

Moustakas, clark. 1994. Phenomenological research methods. United states of america: sage publications.

Mutiganda, jean. 2013. Budgetary governance and accountablity in public sector organisations: an institutional and critical realism approach. Elsivier: hlm. 518-531, (online), dalam (www.elsivier.com/locate/cpa) diakses 10 november 2016.

News pkb jombang. 18 mei 2016. Belum susun apbdes, delapan desa gagal cairkan dana desa. (online), (newspkbjombang.com), diakses 6 september 2016.
O'donnell, guillermo. Horizontal accountability in new democracies. Journal of democracy 9(3): hlm. 112113, (online), dalam (https://muse.jhu.edu/article/16904), diakses pada 15 agustus 2016.

Peraturan menteri dalam negeri ri no. 113 tahun 2014 tentang pengelolaan keuangan desa. (online), (www.kemendagri.go.id), diakses 15 agustus 2016.

Peraturan pemerintah ri no. 8 tahun 2016 tentang perubahan kedua atas peraturan pemerintah no. 60 tahun 2014 tentang dana desa yang bersumber dari anggaran pendapatan dan belanja negara. (online), (http://djpk.kemenkeu.go.id), diakses 15 agustus 2016.

Peraturan kementerian keuangan ri no. 49/pmk. 07 tahun 2016 tentang tata cara pengalokasian, penggunaan, pemantauan dan evaluasi dana desa. (online), (http://djpk.kemenkeu.go.id), diakses 15 agustus 2016.

Riyanto, teguh. 2015. Akuntabilitas finansial dalam pengelolaan alokasi dana desa di kantor desa perangkat selatan kecamatan marangkayu kabupaten kutai kartanegara. Jurnal administrasi negara 3(1): hlm. 127-128, (online), dalam (http://ejournal.an.fisipunmul.ac.id/site/?P=1427), diakses 20 agustus 2016.

Sekretariat daerah bagian hukum kabupaten jombang. 2016. Peraturan bupati no. 5 tahun 2016 tentang tata cara pengalokasian, penyaluran, penggunaan, dan pertanggungjawaban dana desa di kabupaten jombang. Jombang: sekretariat daerah kabupaten jombang.

Sekretariat daerah bagian hukum kabupaten jombang. 2016. Peraturan bupati no. 12 tahun 2016 tentang perubahan atas peraturan bupati jombang no. 5 tahun 2016 tentang tata cara pengalokasian, penyaluran, penggunaan, dan pertanggungjawaban dana desa di 
kabupaten jombang. Jombang: sekretariat daerah kabupaten jombang.

Setyoko, paulus. 2011. Akuntabilitas administrasi keuangan program alokasi dana desa (add). Jurnal ilmu administrasi negara, 11(1): hlm.. 22, (online),

dalam(http://download.portalgaruda.or g/article.php? Article $=32229 \& \mathrm{val}=228$

7, diakses 20 agustus 2016.

Sobur, alex. 2013, filsafat komunikasi: tradisi dan metode fenomenologi. Bandung : pt remaja rosdakarya.

Solso, r, dkk. 2007. Psikologi kognitif edisi kedelapan. Jakarta: penerbit erlangga

Ula, afila. 2014. Akuntabilitas pengelolaan alokasi dana desa di desa menilo kecamatan soko kabupaten tuban. Skripsi tidak diterbitkan. Malang: fe um.

Undang-undang ri no. 6 tahun 2014 tentang desa. Kementrian agraria dan tata ruang badan pertahanan nasional. (online), (http://www.bpn.go.id), diakses 15 agustus 2016.

West, richard dan lynn turner. 2008. Pengantar teori akuntansi: analisis dan aplikasi edisi ketiga. Jakarta: salemba humanika.

Wibisono, darmawan. 2003. Riset bisnis: panduan bagi praktisi dan akademisi. Jakarta: gramedia pustaka utama. 